burden, additional facilities are a ready solution; if they are directed to the possible impairment of the relation between the offender and the probation officer, his recommendation of remission can foreclose that danger whenever it threatens.

\title{
CONCLUSION
}

In addition to whatever its retributive, deterrent and rehabilitative effects may be, the criminal fine could find justification for its use in a system of remuneration for the victims of crimes. Such a system, being a species of restitution, ${ }^{124}$ is subject to the sundry difficulties which confront the genre. Should, for example, the criminal courts move increasingly into a field which has hitherto (at least in recent times) been preoccupied by the civil remedy? If so, what degrees of proof should be required of the claimant, and what administrative procedures for maintenance of the program should be established? Such difficulties are not insuperable, and should not impede further consideration and experiment. Unless innovations of the type suggested herein are instituted, serious thought should be given to a proposal that fines be abolished or severely restricted in application; for present use of them seems rather promiscuous.*

\section{LABOR FACES THE AMENDED ANTI-RACKETEERING $\mathrm{ACT}$}

In United States $v$. Kemble, ${ }^{1}$ the first application of the amended Federal Anti-Racketeering Act ${ }^{2}$ (Hobbs Act), the United States Court of Appeals for the Third Circuit upheld the conviction of a union business agent for attempted extortion. The agent had used violence and threats in an effort to exact wages for "imposed, unwanted, and superfluous" services. This decision suggests that the Hobbs Act may be a potent antilabor weapon with its imposing maximum penalty of twenty years imprisonment. It is particularly significant in light of the judicial reticence that marked the interpretation of other federal legislation aimed with greater specificity and less severity at improper wage exactions.

124. Payment into the fund by a defendant whose conduct has caused no material damage, of course, will not be restitution; but the system can be viewed as reparation by the group of offenders for the group's wrongs.

* Also consult: Best, Crime and the Crmminal Law in the United States (1930) ; Orchard, The Fine System (1917) ; Sen. Doc. No. 181, 54th Cong., 1st Sess. (1896) (report of United States delegates to the Fifth International Prison Congress, Paris, 1895) ; Robinson, Penology in the United States (1922) ; 1 Study of THE BUSINESS OF THE FEDERAL CourTs (1934); Fines, 36 C.J.S. 780 (1943).

1. 198 F.2d 889 (3d Cir.), cert. denied, 344 U.S. 893 (1952).

2. 18 U.S.C. $\$ 420$ (a) (1946) ; reenacted without consequential change, 18 U.S.C. $\$ 1951$ (Supp. 1952). See Legis. 35 Geo. L.J. 362 (1947) and Note, 25 N.C.L. REv. 58 (1946). 
In 1946, just a few months before the passage of the Hobbs Act, Congress approved the Lea. Act, ${ }^{3}$ which was designed to stifle featherbedding practices forced upon the radio industry by the powerful American Federation of Musicians. The broad provisions of the statute set a maximum penalty of two years for the exaction of wages for work not done or for work done but unnecessary to efficient operation by the employer. ${ }^{4}$ However, the only prosecution under the Act met with little success. After the Supreme Court of the United States had sustained the statute's constitutionality ${ }^{5}$ the indictment subsequently was dismissed by the district court $^{6}$ on the grounds that (1) the featherbedding demands were proper under a saving proviso relating to contractual obligations, (2) a strike to enforce these demands did not involve the requisite coercive activity, and (3) there was no evidence that the defendant knew that the employment demanded was unnecessary.

In 1947, on the day on which the Supreme Court passed upon the constitutionality of the Lea Act, Congress passed the Taft-Hartley Act ${ }^{7}$ containing the only other express federal prohibition of the improper exaction of wages. Section $8(\mathrm{~b})$ made it an unfair labor practice for a labor organization or its agents to cause or attempt to cause any employer to pay, in the nature of ar exaction, for services not performed or to be performed. ${ }^{8}$ Two recent Supreme Court decisions interpreting this provision have cast doubt upon its future utility. In American Nezespaper Publishers Association $v$. $N L R B,{ }^{9}$ where the International Typographical Union - forced publishers to pay for bogus type setting, the Court decided that the featherbedding provision of the Act was not violated despite the fact that the bogus type was valueless to the publishers. In $N L R B$ v. Gamble Enterprises, Inc., ${ }^{10}$ the American Federation of Musicians had demanded without success that local orchestras be hired to play overtures, "intermissions," and "chasers" when traveling bands performed. The Court held

3. 60 STAT. 89,47 U.S.C. $\$ 506$ (1946).

4. Under the Act, it is a crime to compel a licensee by "force, violence, intimidation, or duress" to: (1) hire more men than it needs; (2) pay for men who are neither working nor needed; (3) pay more than once for services performed; (4) pay at all for services not to be performed; (5) refrain from broadcasting without paid performance; (6) refrain from broadcasting foreign programs. It also prohibits obstructing the use of technological devices.

5. United States v. Petrillo, 332 U.S. 1 (1947). The District Court had held that the statute was unconstiutional on four grounds: (1) that there was no definite standard to determine whether work is unnecessary to efficient operation by the employer; (2) that there was a violation of equal protection because the statute applied only to the radio industry; (3) that there was a violation of freedom of speech where the statute was applied to picketing; and (4) that there was slavery and involuntary servitude where the Act was applied to striking. United States v. Petrillo, 68 F. Supp. 845 (N.D. Ill. 1946). The Supreme Court reversed the lower court. on the first two grounds and by-passed the others as prematurely raised.

6. United States v. Petrillo, 75 F. Supp. 176 (N.D. Ill. 1948).

7. 61 STAT. 136 (1947), 29 U.S.C. \$141 (Supp. 1952).

8. 61 STat. 140 (1947), 29 U.S.C. $\S 158$ (b) (c) (Supp. 1952). See Note, 52 Col. L. REv. 1021 (1952).

9. 345 U.S. 100 (1953).

10. 345 U.S. 117 (1953). 
that the featherbedding section of the statute was inapplicable although the local bands were unwanted and unnecessary. In these cases, the featherbedding provision of Taft-Hartley was held not to apply when work is done or offered to be done as consideration for wages exacted or attempted to be exacted, although this work is "imposed, unwanted, and unnecessary" to efficient operation by the employer. In light of the impotency of the Lea and Taft-Hartley Acts as weapons against questionable wage exactions, the scope of extortion under the Hobbs Act is of utmost significance to organized labor.

\section{The Original Anti-Racketeering Act Interpreted}

The original Anti-Racketeering Act ${ }^{11}$ passed in 1934 proscribed the obstruction of interstate commerce caused by exacting money through force, violence or coercion [ $\S 2(\mathrm{a})]$ and by obtaining "the property of another, with his consent, induced by wrongful use of force or fear" [\$2(b)]. Provisos to these sections stated that exacting money and property did not include the payment of wages by a bona fide employer to a bona fide employee. Section 6, modifying the Act as a whole, preserved the rights of bona fide labor organizations lawfully carrying out their legitimate objects.

Two important cases helped set the outer limits beyond which neither the wage provisos nor $\S 6$ would extend protection to labor activity. In United States $v$. Compagna, ${ }^{12}$ union leaders personally exacted payments from theatre owners by threatening to call union cameramen out on strike. In Nick v. United States, ${ }^{13}$ union leaders agreed to a reasonable wage contract only after a pay-off promise, which was subsequently enforced by a threat to strike. Since both cases involved individual enrichment rather than union benefit, the convictions were upheld despite the labor safeguards.

In United States v. Local 807, I.B.T., ${ }^{14}$ where union members by actual and threatened physical violence exacted helpers' wages from truckers entering New York City, whether or not their labor was utilized, convictions were reversed on the strength of the wage provisos. The provisos were held by the Supreme Court to include payments to union members who, like stand-by musicians, either worked, although their services were unwanted, or made bona fide offers to work, although their services were refused. ${ }^{15}$ Only payments to union members who refused to work or whose

11. 48 STAT. 979 (1934), 18 U.S.C. \$420(a) (1940).

12. 146 F.2d 524 (2d Cir. 1944), cert. denied, 324 U.S. 867 (1945).

13. 122 F.2d 660 (8th Cir.), cert. denied, 314 U.S. 687 (1941).

14. 315 U.S. 521 (1942).

15. The Court said, "The Circuit Court has referred to the 'stand-by' orchestra device, by which a union local requires that its members be substituted for visiting musicians, or, if the producer or conductor insists upon using his own musicians, that the members of the local be paid the sums which they would have earned had they performed. That similar devices are employed in other trades is well-known. It is admitted here that the stand-by musician has a 'job' even though he renders 
work or offer to work was a sham, were held to be beyond traditional labor activity and outside the wage provisos. ${ }^{16}$

\section{The Hobbs Act Interpreted}

In response to this restrictive interpretation of the statute, ${ }^{17}$ Congress passed the Hobbs Act, ${ }^{18}$ which amended the Anti-Racketeering Act in at least four ways. (1) Robbery and extortion were made the basic crimes. (2) Extortion was defined as "the obtaining of property from another, with his consent, induced by wrongful use of actual or threatened force, violence, or fear." This definition is similar to the language of $\S 2(\mathrm{~b})$ of the earlier Act, except for the italicized words, which apparently were added to incorporate $\S 2(\mathrm{a})$. (3) The wage provisos were omitted.

no actual service. There can be no question that he demands the payment of money regardless of management's willingness to accept his labor. If, as it is agreed, the musician would escape punishment under this Act even though he obtained his 'stand-by job' by force or threats, it is certainly difficult to see how a teamster conld be punished for engaging in the same practice." Id. at 535 . (Italics added).

16. The Court concluded, "We do not mean that an offer to work or even the actual performance of some services necessarily entitles one to immunity under the exception [the wage provisions]. A jury might of course find that such an offer or performance was no more than a sham to disguise an actual intention to extort and to blackmail. But the inquiry must nevertheless be directed to whether this was the purpose of the accused or whether they honestly intended to obtain a chance to work for a wage." Id. at 534 .

17. Opening the debate on the House floor, Congressman Hancock said, "This bill is made necessary by the amazing decision of the Supreme Court in the [Local 807] case . . 3 years ago. That decision practically nullified the antiracketeering bill of 1934. In effect it legalizes in certain labor disputes the use of robbery and extortion. . . The Supreme Court held that ... members [of the union]... were exempt from the provisions of that law when attempting by the use of force or the threat of violence to obtain wages for a job whether they rendered any services or not. . . . We think a mistake was made by the Supreme Court, we are attempting to correct it through enacting a new law. . . " 91 CoNG. REC. 11900 (1945).

Congressman Summers said, "I quote from the [Local 807] decision: "As we have said, the jury was bound to acquit the defendants if it found that their objective and purpose was to obtain by the use or threat of violence the chance to work for the money but to accept the money even if the employers refused to permit them to work. . . It was the purpose of the Judiciary Committee to prevent the rendition of that sort of decision by any court in the future, so the language upon which that holding was based was eliminated." Id. at 11909.

Congressman Rivers said, "As one member of the bar, I disagree with the reasoning in [807] ... I call the procedure referred to in this case . . nothing short of hijacking, intimidation, extortion, and out-and-out highway robbery. . . . The Hobbs bill . . protects interstate commerce from procedures of this nature." Id. at 11917 .

Congressman Whittington said, "The bill is to prevent a repetition of the physical violences by members of labor unions on those engaged in interstate commerce. It is to prevent a repetition of the assaults and attacks upon the drivers of trucks with produce entering New York City and similar cases." Id. at 11913.

In opposition to an amendment by Congressman Cellers which would have restored the original wage proviso, Congressman Jennings said, "That proviso would render it necessary, if this bill accomplished its purpose, for the Supreme Court to annul its opinion in the case where they emasculated the statute before." Congressman Hobbs said, "Of course it would. Such words have already been passed on by the Supreme Court in the Local 807 case. ..." Id. at 11914. The Celler Amendment was rejected by the House. Id. at 11917.

18. See note 2 supra. 
Section 6 was also omitted, but Title Two was inserted as a substitute protection for legitimate labor activities. It provided that the amended Act "shall not be construed to repeal, modify or affect" the Clayton, NorrisLaGuardia, Railway Labor, and amended Wagner (Taft-Hartley) Acts. ${ }^{19}$

The Kemble Case.-In United States v. Kemble, ${ }^{20}$ the first application of the amended Act, both a union and its business agent were convicted of attempted extortion. The agent had used violence and threats in an effort to force a trucker to hire a union helper and pay him a full day's wages, the trucker having nearly completed the unloading of a delivery from his employer at a plant where the union had a closed shop contract.21 On appeal, the Court of Appeals for the Third Circuit affirmed the conviction of the agent, 4-3, and reversed that of the union, 5-2.22 In regard to the agent the majority ruled that, because of the breadth of the statutory phrase "the obtaining of property from another" and because of the legislative history behind the omission of the wage provisos, ${ }^{23}$ an attempt to force the payment of wages for "imposed, unwanted and superfluous services" was an attempt to extort. ${ }^{24}$ Although the court read into the statute the provisions of $\S 6$ of the original Act which preserved the rights of bona fide labor organizations lawefully carrying out their legitimate objects, it held that no state or federal sanction made the agent's violence laref $u l^{25}$

19. 18 U.S.C. $\$ 1951$ (c) (Supp. 1952). Although the Taft-Hartley Act had not been passed when Hobbs became law, it was enacted before Hobbs was amended, and is included in Title Two as the amended Wagner Act.

20. 198 F.2d 889 (3d Cir.), cert. denied, 344 U.S. 893 (1952).

21. Judge McLaughlin, dissenting, inferred that this contract required that union members unload trucks at the plant; however, the trucker's employer was probably not a party to the contract.

22. In regard to the union, the majority applied $\$ 6$ of the Norris-LaGuardia Act which provides that a labor organization cannot "be held responsible . . . for the unlawful acts of ... agents, except upon clear proof of actual participation in, or actual authorization of, such acts, or of ratification of such acts after actual knowledge thereof." 47 STAT. 71 (1932), 29 U.S.C. \$106 (1946). As interpreted in United Brotherhood v. United States, 330 U.S. 395 (1947), this section imposes very stringent requirements of proof. The instant court held that there was no such clear proof, even though the secretary-treasurer of the union threatened trouble at the plant shortly after Kemble's violence if the non-union loading continued. Moreover, the court stated that, regardless of the strict requirments of proof imposed by the Norris-LaGuardia Act, the evidence did not satisfy the less stringent requirements imposed by the usual rules of criminal responsibility for the acts of agents.

Judge Staley concluded in his dissent that the evidence was sufficient if the agent's conduct was extortion, since then the stringent requirements of the NorrisLaGuardia Act, applying only to labor disputes, would not be involved. This reasoning emasculates Norris-LaGuardia since it permits an agent to exceed his authority, limited to the creation of a peaceful labor dispute, and removes those very safeguards provided for principals when agents exceed their authority.

It is suggested that even under the Norris-LaGuardia Act a conviction of a union may be possible without a membership vote authorizing or ratifying an agent's violence, if this violence is authorized by a long standing custom or is participated in by a great number of union members. The Court in the Brotherhood case said that "custom or traditional practice of a particular union can also be a source of actual authorization of an officer to act for and bind the union." 330 U.S. 395, 410 (1946). Likewise, mass membership participation would seem to indicate union participation.

23. See note 17 stipra.

24. 198 F.2d 889,892 (3d Cir. 1952).

25. Ibid. 


\section{The Hobbs Act Analyzed}

The "extortion" punished by the Hobbs Act must be considered by four lines of inquiry: (1) are wages the type of "property" that can be extorted; (2) what is the requisite coercive activity; (3) what is the requisite criminal intent; (4) what are the safeguards of Title Two as an outside limit to labor prosecution.

\section{Property}

The Kemble case held that, because of the legislative history behind the omission of the wage provisos, the broad prohibition of "the obtaining of property" included securing the payment of wages for "imposed, unwanted and superfluous services." 26 As a matter of semantics it would seem that all wage exactions fit equally well within the broad requirements of "property." Moreover, there is no legislative history indicating that certain wage exactions do not involve "the obtaining of property." It is difficult to justify a limitation on the Act if the limitation is to be found in this clause. Such a conclusion is not altered by considering a wage exaction as the exaction of a job.27 In substance the property involved is an employer's money. ${ }^{28}$ Legislative history indicates that the law of extortion is not to be distorted merely because labor activity is in question. ${ }^{29}$

\section{The Requisite Coercive Activity}

Violence.-The agent in the Kemble case swore at the trucker, threatened him physically, pushed crates toward his feet, and let air out of his tires. Clearly this constitutes "actual or threatened force, violence, or fear. . . ." 30

Striking or Picketing.-Section 2(a) of the old Act punished the exaction of money through "coercion." 31 Both the Compagna and Nick cases ${ }^{32}$ held that threats to strike constituted the necessary coercion. How-

\section{Ibid.}

27. Cf. People v. Warden of City Prison, 145 App. Div. 861, 130 N.Y. Supp. 698 (1st Dep't 1911) ("property" in the New York extortion statute includes the right to employment). But cf. People v. Cuddihy, 151 Misc. 318, 271 N.Y. Supp. 450 (Ct. Gen. Sess. 1934), aff'd, 243 App. Div. 694, 277 N.Y. Supp. 960 (1935).

28. Compare Regina v. Bull, 13 Cox C.C. 608 (1877) (obtaining money by false pretenses).

29. Congressman Gwynne said, "This bill simply would protect interstate commerce from robbery and extortion, no matter by whom these crimes were committed." 91 Cong. REC. 11904 (1945).

Congressman Whittington said, "It punishes extortion and robbery no matter by whom committed. ..." Id. at 11913 .

Congressman Hobbs said, "Crime is crime, no matter who commits it. Robbery is robbery and extortion is extortion, whether or not the perpetrator has a union card in his pocket. . . " Id. at 11912 .

30. See text after note 18 supra.

31. See text at note 11 supra.

32. See notes 12 and 13 supra. 
ever, the word "coercion" was omitted from the Hobbs Act."3 It is therefore arguable that threats to strike (and, $a$ fortiori, picketing) are not now punishable, even in the Compagna-Nick situations. There is legislative history to support this position. ${ }^{\mathbf{3 4}}$ However, the omission of the word "coercion" should not be given so radical an effect. The New York extortion statute, ${ }^{35}$ which served as the prototype for the Hobbs Act, ${ }^{36}$ also does not punish "coercion" per se, but under it situations like Compagna and Nick have been held to be extortion on the grounds that threats to strike, and perhaps picketing, create a "fear" of injury to business property. 37 The instilling of "fear" is also punishable by the Hobbs Act, ${ }^{38}$ although it omits the New York Act's lengthy definition of "threats which constitute fear," including "fear of unlawful injury to property." However, this omission would seem to be immaterial in light of the fact that fear of injury to property is so thoroughly ingrained in typical extortion statutes, ${ }^{39}$ that it is now implicit. Moreover, the proposition is weak that the Hobbs Act applies only to the strong-arm racketeering methods which existed in the Local 807 case, where the truckers were forced to purchase immunity from physical violence. The Act was passed to extend, not restrict, federal anti-racketeering legislation ${ }^{40}$ and racketeering objectives also can be accomplished by apparently legitimate union means. It therefore seems probable that the Campagna and Nick situations, involving threats to strike, contain the requisite coercive activity

33. The possiblity that striking and picketing would constitute "coercion" was brought to the attention of the House Committee which proposed the Hobbs Act, Hearings before Subcommittee No. 3 of the Committee on the Judiciary on $H . R$. 5218, H.R. 6752, H.R. 6872, H.R. 7067, 77th Cong., 2d Sess. 126, 227, 234 (1942). Congressman Thom proposed that "coercion" be deleted. Id. at 158.

34. Congresswoman Summer stated that "There have been complaints that in the case of strikes an attorney has gone in and asked an operator for something like $\$ 15,000$ or $\$ 20,000$.. . to stop a strike. Is there anything in this bill about that?" Congressman Jennings: "Not a thing. This does not have a thing in the world to do with strikes." 91 CoNG. REC. 11912 (1946).

Congressman Gwynne stated that the taking must be "by violence, by personal violence, or by actual threats of personal violence. . . ." Id. at 11903.

Congressman Hancock said the Act "cannot apply to a threatened strike because strikes are lawful, they are not wrongful." Id. at 11902 .

35. N.Y. Penat CoDE $\$ 850$.

36. Congressman Hancock said, "The bill contains definitions of robbery and extortion which follow the definitions contained in the laws of the State of New York." 91 CoNG. REC. 11900 (1946).

Congressman Hobbs said, "The definitions in this bill are copied from the New York Code substantially." Ibid.

37. People v. Lamm, 292 N.Y. 224, 54 N.E.2d 374 (1944) (threats to keep union members out of a certain working area); People v. Bernoff, 292 N.Y. 230, 54 N.E.2d 376 (1944) (threats to call and actually calling strikes); People v. Weinseimer, 117 App. Div. 603, 102 N.Y. Supp. 579 (1st Dep't 1907) (threats to continue a strike); People v. Wilzig, 4 N.Y. Crim. Rep. 403, 414, 416 (1886) (a peaceful boycott).

38. See text after note 18 supra. The possibility that striking would constitute "fear" was brought to the attention of the House Committee which proposed the Hobbs Act, but without response. Hearings, supra note 33, at 127.

39. See comment, 44 MICH. L. REv. 461, 463 (1945).

40. See note 17 supra. 
under the Hobbs Act. Furthermore, the coercive characteristics of a threat to strike do not necessarily depend upon the nature of the labor objective. Any threat to strike may be equally as coercive although a proper objective is in mind. Picketing, however, is perhaps not as inherently coercive. ${ }^{41}$

\section{Crininal Intent}

The original Anti-Racketeering Act defined "wrongful" to be "in violation of the criminal laws of the United States or of any State or Territory." $\$ 2$ No cases construed this definition, and the Hobbs Act omitted it. This omission may mean that "wrongful" does not necessitate a showing of unlawfulness under other criminal legislation. ${ }^{43}$ But, even so, "wrongful" probably does necessitate a showing of criminal intent (public wrong) rather than mere tortious intent (private wrong).44 The New York extortion statute requires proof a criminal intent. ${ }^{45}$ Moreover, it was held in Morissette $v$. United States ${ }^{46}$ that where a statute omits a criminal intent traditionally included in common law and statutory law, Congress will be presumed to have intended to include it, absent a contrary direction.

Traditional Criminal Law Claim-of-right.-Under extortion statutes of the New York type some courts have held that criminal intent requires merely the showing of wrongful means. ${ }^{47}$ They have rejected the possibility that criminal intent may be negated, in certain limited circumstances, by a showing of a bona fide claim of right to the end involved, even though the means are wrongful. Apparently the majority in the Kemble case

41. Compare Hughes v. Superior Court, 339 U.S. 460, 465 (1950) with Swenson v. Seattle Central Labor Council, 27 Wash.2d 193, 206, 177 P.2d 873, 880 (1947). It should be noted that where the coercive activity is striking or picketing, an extortion conviction under the Hobbs Act is probably not precluded by the Federal Constitution. Compare Dorchy v. Kansas, 272 U.S. 306 (1926), and Giboney v. Empire Storage \& Ice Co., 336 U.S. 490 (1949) with the district court's holding under the Lea Act, see note 5 supra.

42. 18 U.S.C. $\$ 420 \mathrm{~b}(\mathrm{a})$ (1940).

43. This omission was brought to the attention of the House Committee which proposed the Hobbs Act, Hearings, supra note 33, at 196. No explanation was given by the Committee.

44. Chief Judge Biggs, dissenting in the Kenble case, so concluded. He would have reversed the conviction of the agent since the trial court merely read the Hobbs Act without giving a specific instruction requiring proof of a criminal rather than a tortious intent. The majority affirmed the conviction of the agent without mentioning the problem of criminal intent. It perhaps felt that the requirement of a criminal rather than a tortious intent was self-evident to a jury. $C f$. State v. Louanis, $79 \mathrm{Vt}$. 463, 65 Atl. 532, 534 (1907): "It was not necessary for the court to define 'extort' to the jury. It is a common word, used in the statute in its ordinary sense, and the court might well assume that the jury understood it."

45. People v. Gassman, 182 Misc. 878, 885-886, 45 N.Y.S.2d 709, 715 (Ct. Gen. Sess. 1943) ; People v. Cuddihy, 151 Misc. 318, 271 N.Y. Supp. 450 (Ct. Gen. Sess. 1934), aff'd, 243 App. Div. 694, 277 N.Y. Supp. 960 (1935) ; People v. Feld, 262 App. Div. 909, 28 N.Y.S.2d 796 (1941); People v. Weinseimer, 117 App. Div. 603, 102 N.Y. Supp. 599 (1st Dep't 1907).

46. 342 U.S. 246 (1952). See also Seaboard Oil Co. v. Cunningham, 51 F.2d 321,324 (5th Cir. 1931), "the general rule is that in all statutory crimes involving moral turpitude criminal intent is an implied, necessary ingredient."

47. In re Sherin, 27 S.D. 232, 130 N.W. 761 (1911); People v. Beggs, 178 Cal. 79, 172 Pac. 152 (1918); State v. Phillips, 62 Idaho 656, 115 P.2d 418 (1941). 
adopted this view. ${ }^{48}$ The New York courts, however, are probably committed to a claim-of-right approach, ${ }^{49}$ which would seem to be the better one. The common element of the law of theft is a taking of property with a felonious intent. ${ }^{50}$ Felonious intent may be negated by a showing of claim-of-right to the property obtained, whether the crime is larceny, ${ }^{, 51}$ or embezzlement ${ }^{52}$ where the offense is against property alone, or robbery ${ }^{33}$ where the offense is against both person and property. Extortion is merely a species of aggravated theft, almost indistinguishable from robbery. ${ }^{54}$ Therefore, it seems reasonable to conclude that a legitimate

48. Judge Staley, in dissent would have required a showing of both wrongful means and ends.

49. See cases at note 45 sipra. See also People v. Sheridan, 186 App. Div. 211, 174 N.Y. Supp. 327 (2d Dep't 1919) where a charge as to defendant's claim of right only to the means used was refused. Felonious intent was required under an earlier New York extortion statute. See People v. Griffin, 2 Barb. 427 (N.Y. 1848). Note also that it is essential under the New York statute punishing the taking of unlawful fees by a public officer; see People v. Clark, 242 N.Y. 313,151 N.E. 631 (1925). Cf. People v. Flack, 125 N.Y. 324, 26 N.E. 267 (1891) where it was held that the law will not presume the criminal intent necessary to a conspiracy conviction from the doing of an unlawful act.

50. See Morissette v. United States, 342 U.S. 246, 260-261 (1952).

51. State v. Sawyer, 95 Conn. 34, 110 At1. 461 (1920); Thomas v. Kessler, 334 Pa. 7, 5 A.2d 187 (1933); People v. Shaunding, 268 Mich. 218, 255 N.W. 770 (1934) ; People v. Devine, 95 Cal. 227, 30 Pac. 378 (1892) (statute requires felonious intent).

52. Ridge v. State, 192 Ind. 639, 137 N.E. 758 (1923) ; People v. Parker, 355 I11. 258,189 N.E. 352 (1934); Brown v. State, 92 Fla. 538, 109 So. 438 (1926) (statute requires felonious intent).

53. Butts v. Commonwealth, 145 Va. 800, 133 S.E. 764 (1926); People v. Erlandson, 360 I11. 214, 195 N.E. 670 (1935) ; People v. Sheasbey, 82 Cal. App. 459 , 255 Pac. 836 (1927) (statute requires felonious intent); cf. Moyers v. State, 186 Ga. 446, 197 S.E. 846 (1938).

54. The Commisioners who drafted the New York Penal Code stated that "Four of the crimes affecting property, require to be somewhat carefully distinguished; robbery, larceny, extortion and embezzlement. The leading distinctions between these, in the view taken by the Commissioners, may be briefly stated thus; All four include the criminal acquisition of the property of another. In robbery this is accomplished by means of force or fear and by overcoming or disregarding the will of the rightful possessor. There is a taking of property from another against his consent; the physical power to resist being overcome by force, or what is equivalent in law, the moral power to refuse being prostrated by fear. In larceny there is still a taking but it is accomplished by fraud or stealth; the property is taken, not against the consent of the owner, but without it. In extortion there is again a taking. Now it is writh the consent of the party injured; but this is a consent induced by threats, or under color of some official right. ..." COMMISSIONERS' REPORT, New York Penal CODE $\$ 584$ (1865).

Thus, extortion was included to supplement robbery by penalizing a taking with the consent of the owner; People v. Barondess, 61 Hun 571, 576, 16 N.Y. Supp. 436, 438 (1st Dep't 1891). The court in In ve Sherin, 27 S.D. 232, 130 N.W. 761 (1911) was mistaken in its conclusion that extortion is merely a lesser degree of robbery, requiring a showing only of wrongful means. The New York Commissioners gave no indication that extortion, unlike robbery, see note 55 infra, does not require proof of a felonious intent. Quite to the contrary, their brief note to extortion, see $\$ 613$, cites only one case, People v. Whaley, 6 Cow. 661 (N.Y. 1827); there the court instructed the jury that extortion under color of official right demands a showing of a corrupt intent which may be negated by a claim of right. It is significant also that Congress, in borrowing the New York definitions of robbery and extortion, see note 36 supra, imposed the same maximum penalty for both crimes. It is difficult to conclude that Congress considered extortion merely a lesser degree of robbery, requiring a showing only of wrongful means, particularly in light of the severity of punishment. 
defense to extortion is the absence of wrongful ends, particularly in light of the Morissette case. ${ }^{55}$

Of the limited number of objectives which negate criminal intent under the traditional law of robbery and extortion, there are only two examples that are of assistance in discerning under what circumstances wages can be extorted. It is generally held that robbery is not involved when force is used to collect a debt.5B A New York court apparently has arrived at the same conclusion under the extortion statute on the grounds that the ultimate object is "not the 'lucri causa' which must always characterize the act." the value of the goods is robbery, while a forced sale for a fair and adequate consideration may not be. In the famous Fisherman's Case, ${ }^{58}$ where fish were taken from a fisherman against his will, doubt was expressed concerning the justification of a robbery conviction because the fisherman was paid more than the selling price of the fish. The court's doubt was apparently predicated on the belief that there was "no such enormity in the intention of the wrongdoer as is implied in the notion of felony." 59

The cases involving the collection of a debt by force would prevent an extortion conviction where an employee procured by force the payment of wages due under an existing contract. They might also protect a demand by an employee that an employer who hired a non-union man in violation of a closed shop contract must pay an amount equivalent to the wages paid the non-union man. Here the demand is for a debt owed under the contract as damages for breach of the contract. ${ }^{80}$

Where an employment contract is procured by force, however, the cases concerning the collection of a debt are of no assistance to the employee since they involve debts incurred without coercion. ${ }^{61}$ Here the

55. The Commissioners concluded that a taking of property without a wrongful intent amounts at most to a trespass. In their note to robbery they said, "This definition embodies substantially the elements suggested by 2 REV. STAT., 667 , $\$ 55$, 56; the word 'wrongful' being substituted for 'feloniously.' Three elements are necessary to constitute the offense of robbery, as it is generally understood. 1. A taking of property from the person or presence of its possessor. 2. A wrongful intent amounts at most to a trespass. In their note to robbery they said: "This The first and second of these elements, the third being wanting, constitute simple larceny. The first and third, without the second, amount at most to a trespass. . . ." Comamissioners' Report, New York Penal Code $\$ 280$ (1865). Compare treatment of theft by the American Law Institute in the MOder Penal Code $\$ 206$, comment $b$ (Tent. Draft No. 1, 1953) (". . . a genuine belief in one's legal right shall in all cases be a defense to theft. Persons who take only what they believe themselves entitled to constitute no significant threat to our property system and manifest no character trait worse than ignorance.")

56. See cases at note 53 supra.

57. People v. Cuddihy, 151 Misc. 318, 324, 271 N.Y. Supp. 450, 456 (Ct. Gen. Sess. 1934). But see People v. Conforti, 72 N.Y.S.2d 458 (1947).

58. 2 East, Pleas of the Crown 661-662 (1803).

59. 1 Hawkins, Pleas of the Crown 236 (7th ed. 1795).

60. See Conway's Express, 87 N.L.R.B. 972 (1948) where under similar circumstances the NLRB dismissed a charge of featherbedding on the grounds that the demand was made under color of right.

61. Compare McKeown v. State, 34 Okla. Cr. 381, 246 Pac. 659 (1926). 
Fisherman's Case may be of some aid in a situation where the employer admits that he needs another man but declines for some reason to hire this particular employee. Coerced employment may be justified by the fact that the employee performs a necessary service and gives full and adequate consideration for the wages paid. There are, however, obvious difficulties in applying the forced-sale-of-fish analogy to the case of forced employment since the employment contract has the unique characteristics of any personal service contract. The Fisherman's Case would be of little assistance in a situation where the employer insists that another man is not needed. To justify this coerced employment requires a conclusion that an "employee" can overrule the seasoned judgment of the employer concerning the efficient running of his own plant.

The Fisherman's Case analogy is difficult to apply even in instances involving demands by present employees for a reasonable wage increase, for pay during vacations, rest periods, or travel time, for room and board, or time-and-a-half. The employees may argue that these demands are merely incidental to regular, necessary employment and are means to secure a reasonable wage in exchange for valuable services rendered to the employer. To accept this argument, however, is to admit that the wrongdoer can force the fisherman to sell his fish at a price less than that demanded by the latter. The essence of the Fisherman's rule-if it is a rule ${ }^{62}$-is that the wrongdoer unquestionably gave fair consideration for the fish. .

A Suggested Approach.-The fact that the traditional claim-of-right theory under the law of robbery and extortion affords limited protection for wage demands is not surprising. Few if any prosecutions for the exaction of wages have arisen under these laws, and courts have not been forced to delineate the requisite felonious intent. An attempt to define this intent when labor conduct is involved must of necessity be tempered by the climate of public opinion about such activity. Federal safeguards such as those embodied in the Clayton, Norris-LaGuardia, Railway Labor, Wagner, and Taft-Hartley Acts are particularly significant. Before the passage of the Lea and Taft-Hartley Acts, there was no Federal legislation which expressly made wage exactions of any type an improper labor objective. Federal courts had held that the Clayton and Norris-LaGuardia Acts ${ }^{63}$ prevented the application of the Sherman Act to featherbedding wage demands. ${ }^{64}$ State courts had ruled that little Norris-LaGuardia Acts prohibited the

62. See Kenny's Outuines of Criminal Law 243 (Turner ed. 1952).

63. See notes 100-102 infra.

64. United States v. Carrozzo, 37 F. Supp. 191, 195, 196 (N.D. I11.), aff'd per curiam sub nom. United States v. International Hod Carriers, 313 U.'S. 539 (1941) (strikes and threats to strike to deter use of a labor-saving device or to compel employment of the same number of men who would have been employed but for the device). See also United States v. American Federation of Musicians, 47 F. Supp. 304 (N.D. Ill. 1942), aff'd withont opinion, 318 U.S. 741 (1943); United States v. Bay Area Painters and Decorators, Joint Comm., Inc. 49 F. Supp. 733, 737 (N.D. Cal. 1943). See text at note 110 infra. 
enjoining of featherbedding. ${ }^{65}$ Moreover, the Lea Act was emasculated by judicial construction, ${ }^{B 6}$ and the Taft-Hartley Act was not intended to condemn the bogus type-setter or the stand-by musician.

In light of this history, it is suggested that there may be no extortive intent under the Hobbs Act in the coerced employment situation where the employee makes a bona fide offer to work, even though he intends to accept wages if work is not permitted to be done. The Act may proscribe only the exacting of "protection" money, i.e., payments where work is refused to be done, or is done or offered to be done merely as a sham. ${ }^{67}$ Sham for this purpose would have a very limited definition. In certain extreme instances, it may include a non-existent job, in the sense that the job is completely foreign to the employer's customary operations. It may also encompass jobs for which the "employee" is obviously unqualified. Finally, it may include the situation where the wages demanded are totally disproportionate to the amount of work to be done.

Such a limitation on extortive intent was perhaps in the mind of Judge Learned Hand when he said in the Local 807 case that "The wrong is the extortion of money without quid pro quo, and a bona fide tender is the only step that the putative employee can ever take towards performance. . . ." 88 The Supreme Court in the Local 807 case never ruled on Judge Hand's interpretation of the requisite criminal intent; it held that where the "employee" made a bona fide offer to work, he was protected by the wage provisos in the original Act. ${ }^{69}$ Absent the wage provisos, the Court might nevertheless have held that extortion was not involved where the "employee" offered to work, because there was "no such enormity in the intention of the wrongdoer as is implied in the notion of" ?0 the serious felony of extortion. ${ }^{71}$ This limitation on the nature of felonious intent in the Hobbs Act would not necessarily make the conviction in

65. Motion Picture Mach. Union v. Rialto Theatre Co., 25 Del. Ch. 347, 17 A.2d 836 (Sup. Ct. 1941) ; Steerman v. Krouse, 36 Pa. D. \& C. 475 (1939); Bayer v. Brotherhood of Painters, 108 N.J. Eq. 257, 154 Atl. 759 (Ct. Err. \& App. 1931). Contra: Opera on Tour, Inc. v. Weber, 285 N.Y. 348, 34 N.E.2d 349, cert. denied, 314 U.S. 615 (1941); Haverhill Strand Theatre, Inc. v. Gillen, 229 Mass. 413 , 118 N.E. 671 (1918).

66. See text at note 6 supra.

67. Sham payments involved extortion under the original Act, see note 16 supra. Apparently Judges McLaughlin and Staley dissenting in Kemble would limit the Act to protection payments. Judge McLaughlin stated that the Act cannot include broad featherbedding provisions like the Lea Act, because the Supreme Court in United States v. Petrillo, 332 U.S. 1 (1947), when answering the argument that Lea singled out radio employees for featherbedding regulation, failed to refer to the alleged prohibitions in the Hobbs Act. However, it is the policy of the Court not to interpret statutes when the instant facts do not raise issues thereunder.

68. United States v. Local 807, I.B.T., 118 F.2d 684, 687 (2d Cir. 1941).

69. See text at note 14 supra.

70. See text at note 59 supra.

71. There is language in the Local 807 case indicating that the Court might have drawn such a conclusion, see notes 15 and 16 supra. It is doubtful whether the court would have affirmed a conviction of the Teamsters even without the wage provisos since then a host of featherbedding convictions would have been possible under the Act, including that of stand-by musicians. 
the Kemble case improper. Since the work was nearly completed when Kemble made his demands for a full day's wages, any work done by Kemble or a member of his union would have been a sham. ${ }^{72}$

The suggested interpretation of extortive intent gives no effect to the omission of the wage provisos after the Local 807 case and frustrates the obvious congressional aim to punish violent disruptions of interstate commerce by labor ${ }^{73}$ The paradox of the legislative history is that Congress, so determined to punish labor violence, may have overshot its mark. By choosing the compound felony of extortion as its weapon, it required the proving of felonious intent ${ }^{74}$ which may not be involved in the coerced employment situation where the "employee" makes a bona fide offer to work.

The justification for giving no effect to the omission of the wage provisos becomes apparent when the alternatives are considered. (1) Minimal effect could be given to the omission by construing Hobbs as proscribing like the featherbedding provisions of the Taft-Hartley Act, ${ }^{75}$ a bona fide offer to work where the "employee" intended to accept wages even if employment were refused. (2) Additional effect can be given by a conclusion that the Hobbs Act, like the featherbedding sanctions of the Lea Act, ${ }^{76}$ prohibits a demand for employment which is unnecessary to efficient operation by the employer. (3) Giving maximum effect would result in the Racketeering Act, unlike either Taft-Hartley or Lea, proscribing a demand for employment which is necessary to efficient operation by the employer.

The legislative history indicates that Congress focused upon the problem of the Local 807 case as one of improper labor means (violence) rather than improper labor objectives (featherbedding demands). ${ }^{77}$ The House Committee on the Judiciary, which ultimately proposed the Hobbs Act on the floor of the House, rejected two alternative bills which dealt specifically with featherbedding. ${ }^{7 \varepsilon}$ Moreover, when Congress imposed sanctions on

72. Under this theory, the failure of the Kemble court to reverse the conviction in light of the fact that the trial court gave no charge regarding felonious intent can best be explained by the doctrine of non-prejudicial error, in that the offer was a sham as a matter of law. It is questionable, however, whether the application of this doctrine is appropriate in Kemble, since the essential consideration is the defendant's state of mind. Kemble may have felt that his demands were not a sham; see text at note 6 supra for a similar question under the Lea Act.

73. See note 17 supra.

74. This was articulated by Judge Staley in dissent in the Kemble case. He noted that "[ $t]$ he fact that physical violence was threatened should not be allowed to confuse the picture. If Congress had enacted legislation making the obstruction of commerce by violence or threats of violence a crime, these defendants would stand properly convicted. But no such offenses were ever made into law; and this court should not judicially legislate such offenses. The felonions taking of property from another by the use of violence or threats of violence, whether it be denominated extortion or robbery, is really a compound felony, for the actor has offended both the person and the property of the victim." 198 F.2d 889, 899 (Italics added).

75. See text at note 93 infra.

76. See text at note 4 supra.

77. See note 17 supra.

78. Hearings, supra note 33 , at $104,121,122,123$. These bills contained broad provisions of the Lea Act type. 
featherbedding under the Lea and Taft-Hartley Acts, it used specific statutory language. ${ }^{79}$ Furthermore, the legislature penalized coercion of featherbedding under the Lea Act by a maximum sentence of one year, whereas the maximum penalty under the Hobbs Act is twenty years. Finally, Congress did not rely solely on the Hobbs Act to control featherbedding since after its passage featherbedding was made an unfair labor practice under the Taft-Hartley Act.

Since congressional history does not indicate that Congress envisioned the Hobbs Act as a weapon against featherbedding demands, featherbedding as defined in the Lea and Taft-Hartley Acts should not supply the requisite criminal intent under Hobbs. Unlike the Lea Act proscription, guilt should not depend upon whether the "employee" intended to exact wages for work unnecessary to efficient operation by the employer. The severe penalities of Hobbs should not rest upon the ex post facto determinations of timeand-motion-study experts. ${ }^{80}$ Moreover, sanctions under Hobbs, unlike Taft-Hartley, should not depend upon whether the "employee" making the offer to work intended to exact wages only for work permitted to be done. The Taft-Hartley rule would force the "employee" to exert continued pressure on the employer until he was permitted to work since then there would be little doubt that the employee intended to exact wages only for work permitted to be done. As Judge Learned Hand said in the Local 807 case, "Guilt is personal to the wrong-doer; it would be absurd to make it depend upon the fact that the employee had not gratuitously persisted in pressing his unwelcome services upon the employer. That would excuse the more heinous offence, and penalize the more venial. . . ." 81

A conclusion that Hobbs will not punish featherbedding proscribed by the Lea and Taft-Hartley Acts is consistent with the history of the New York type statute. There is no indication that these statutes were enacted or have been applied as sanctions upon. featherbedding. They were aimed at racketeering of the "Kelly and Dillinger" type and have been used against labor activity only in the Compagna and Nick ${ }^{82}$ situations where the labor leaders' objective is individual enrichment rather than union benefit. ${ }^{83}$

Thus, a conclusion that extortion is not involved when an "employee" makes a bona fide offer to work is not at all improbable in states having the New York type statute. Such a limitation would seem vital in light of the fact that threats to strike and striking have been held to supply the requisite coercive activity. ${ }^{84}$ Without this limitation, striking to force employment of the bogus type-setter or the intermission-playing musician, or

79. See note 4 and text at note 8 supra.

80. The Supreme Court stated that under the Lea Act the fact that an employer said that a particular job was unnecesary was not conclusive, United States v. Petrillo, 332 U.S. 1,6 (1947).

81. United States v. Local 807, I.B.T., 118 F.2d 684, 687 (2d Cir. 1941).

82. See text at note 12 supra.

83. See cases at note 37 supra.

84. Ibid. 
to secure a reasonable wage increase would be extortion. Felonious intent defined in terms of featherbedding is improper; traditional robbery and extortion criteria are difficult to apply; and the possible protective provisions of a Title Two are not available under the state statutes. Since Congress chose to enact the New York type statute, federal courts should give great weight to how extortion would be defined in state courts. Only after extortion is adequately defined should they look at the interaction of the substantive crime with the possible labor safeguards in Title Two.

\section{Title Two}

Immediately after the Local 807 case, Congress passed a statute similar to the Hobbs Act in its present form except that Title Two was omitted. This statute was vetoed by the President as part of the larger Case Bill. In his veto message, the President stated that "On its face, this section does no more than prohibit all persons, whether union representatives or employees or others, from interfering with interstate commerce by robbery and extortion." He added that he was in "full accord with the objectives" of the Hobbs Bill but that "some question may arise from the fact that . . . [the bill] . . . omits from the original act the provision that it was not to be construed so as to 'impair, diminish, or in any manner affect the rights of bona fide labor organizations in lawfully carrying out the legitimate objects thereof"." The President concluded that "it should be made clear in express terms that . . . [the bill] . . . does not make it a felony to strike and picket peacefully and to take other legitimate and peaceful concerted action." 35 Congress satisfied this Presidential desire when it reenacted the Hobbs Bills by incorporating Title Two ${ }^{86}$ which provided that the Act "shall not be construed to repeal, modify or affect" the Clayton, NorrisLaGuardia, Railway Labor, and amended Wagner (Taft-Hartley) Acts. ${ }^{87}$

The court in the Kemble case interpreted Title Two to mean the same as $\S 6$ of the earlier Act. ${ }^{88}$ This interpretation overlooks the fact that, at least in form, Title Two is quite different from $\S 6$. A more appropriate approach to Title Two requires first an investigation of the labor safeguards provided by the enumerated statutes, and then a construction of the phrase that nothing in the Hobbs Act shall be "construed to repeal, modify or affect" these statutes.

\section{92 CoNG. REC. 6676 (1946).}

86. Congressman Hobbs said, "Let me point out that when you are striking, when you are picketing, when you are organizing a labor union, or engaging in any legitimate labor function, then you are operating under some one of those four laws that are specifically exempted in this bill by title III." [Iater called title II]. 91 CoNG. REC. 11900 (1946). The President in his message accompanying his signature of the bill stated that the Attorney General "makes reference, in particular, to title II of the bill. . . [He] also advises that the legislative history shows that the bill is not intended to deprive labor of any of its recognized rights, including the right to strike and to picket, and to take other legitimate and peaceful concerted action." 92 CoNG. Rec. 8299 (1946).

87. See note 19 supra.

88. See text at note 25 supra. 
Taft-Hartley Act.-Although the amended Wagner (Taft-Hartley) Act safeguards labor's right to strike and picket, ${ }^{89}$ this protection is by no means absolute. It is possible that employees who strike against an unfair labor practice committed by an employer may lose the protection of the Act. It has been held that their usual right to reinstatement is sacrificed where the strike is a sit down strike ${ }^{80}$ or mutiny. ${ }^{91}$ Furthermore, under the TaftHartley Act it is an unfair labor practice for a labor organization or its agents to engage in certain specified activities. Prohibited conduct includes, for example, striking or picketing to exert secondary pressure on an employer, striking to force an employer to bargain when another union is certified, jurisdictional striking, and striking or picketing to enforce featherbedding demands. ${ }^{22}$

This featherbedding provision must be analyzed closely since it is Taft-Hartley's only specific prohibition on improper wage exactions and is therefore most intimately connected with coerced employment.

In light of the decisions by the Supreme Court involving the bogus type-setter and intermission-playing musician, ${ }^{93}$ the featherbedding provisions of Taft-Hartley do not apply when work is done or offered to be done as consideration for wages exacted or attempted to be exacted, although this work is unnecessary to efficient operation by the employer. On the other hand, the court was not forced to pass on the validity of an offer to work coupled with an alternative demand that wages be paid even though no work is permitted to be done. This practice would seem to be improper because of the alternative intent to exact wages without working. Featherbedding clearly is involved where there is no offer to work, and may be found where work is done or offered to be done merely as a sham in the sense that little or no work is done or offered to be done. Finally, an unfair labor practice is probably involved in the Compagna and Nick situations ${ }^{94}$ where a labor leader makes no pretension about employment but merely feathers his own nest.

Where a union strikes or pickets to force employment and this activity under the Taft-Hartley Act results in loss of right to reinstatement or amounts to an unfair labor practice, Title Two probably would not prevent a conviction under the Hobbs Act. Such a conviction would not "repeal, modify or affect" the protective spirit of the Taft-Hartley Act, which in its own jurisdictional realm provides no safeguard for this labor activity. However, where a union strikes or pickets to force employment and this activity does not invoke sanctions under the Act, Title Two prob-

89. 61 STAT. 140, 151 (1947), 29 U.S.C. \$\$ 157, 163 (Supp. 1952).

90. NLRB v. Fansteel Metallurgical Corp., 306 U.S. 240 (1939).

91. Southern S.S. v. NLRB, 316 U.S. 31 (1942).

92. 61 Stat. 140 (1947), 29 U.S.C. $\$ 158$ (b) (Supp. 1952).

93. See text at note 9 supra.

94. See text at note 12 sipra. 
ably does prevent a conviction under the Hobbs Act.95 Such a conviction would "repeal, modify or affect" the Taft-Hartley Act which provides a safeguard for this labor activity. It is specious to argue that a Hobbs conviction would not "repeal, modify or affect" the Act because despite the conviction the labor activity in question is still not an unfair labor practice or enjoinable under Taft-Hartley. Congress added Title Two to the Hobbs Act to prevent convictions where the conduct in question was within the protective spirit of the enumerated statutes, not to prevent a possible change in the application of those statutes because of the Hobbs Act. It is difficult to see how extortion penalties under the Hobbs Act could authorize any such change. ${ }^{96}$

It seems reasonable to conclude that the Taft-Hartley Act will provide only a limited protection to labor conduct otherwise amounting to extortion under Hobbs. Although the featherbedding provisions are narrowly drawn, other labor "improprieties" will eliminate the protections even when striking or picketing is involved. Moreover, where the coercive activity is labor violence, the Act will probably afford no safeguards. Only in the situation where the violence is merely incidental to the coercive conduct, such as occasional violence along the picket line, would a different conclusion be possible. Even a strike becomes improper under Taft-Hartley where its fundamental characteristic is violence, e.g., a sitdown strike. ${ }^{97}$

Clayton and Norris-LaGuardia Acts.-Section 20 of the Clayton Act ${ }^{88}$ provides that certain enumerated labor activities shall not "be considered or held to be violations of any law of the United States." This section was emasculated by the Supreme Court in Duplex Co. v. Deering ${ }^{99}$

95. A difficulty with this proposition is that a jury in applying Title Two may have to invade the realm of the NLRB and decide whether the activities in question were unfair labor practices. The District Court in the Kemble case gave a general charge to the jury regarding the protections of the labor statutes in Title Two.

96. Title Two includes a section of the Sherman Act which exempts labor activity from Sherman proceedings, 15 U.S.C. $\$ 17$ (1946). It is difficult to understand this inclusion since a possible extortion conviction under Hobbs would not remove the Sherman exemption.

97. NLRB v. Fansteel Metallurgical Corp., 306 U.S. 240 (1939).

98. "And no such restraining order or injunction shall prohibit any person or persons, whether singly or in concert, from terminating any relation of employment, or from ceasing to perform any work or labor, or from recommending, advising, or persuading others by peaceful means so to do; or from attending at any place where such person or persons may lawfully be, for the purpose of peacefully obtaining or communicating information, or from peacefully persuading any person to work or to abstain from working; or from ceasing to patronize or to employ any party to such dispute, or from recommending, advising, or persuading others by peaceful and lawful means so to do; or from paying or giving to, or withholding from, any person engaged in such dispute, any strike benefits or other moneys or things of value; or from peaceably assembling in a lawful manner, and for lawful purposes; or from doing any act or thing which might lawfully be done in the absence of such dispute by any party thereto; nor shall any of the acts specified in this paragraph be constmed or held to be violations of any laze of the United States." 38 STAT. 738 (1914), 29 U.S.C. $\$ 52$ (1946) (Italics added).

99. 254 U.S. 443 (1921). 
where it was held that $\S 20$ would not prevent a labor conviction under the Sherman Anti-Trust Act unless union activities were directed against an employer by his ozm employees. Congress then passed the NorrisLaGuardia Act which provides that when there is a "labor dispute," 100 federal courts have no power to enjoin certain enumerated labor activities not involving violence or fraud.101 Moreover, even with violence or fraud, certain procedural and substantive safeguards must be satisfied before an injunction may issue. ${ }^{102}$ In United States $v$. Hutcheson, ${ }^{103}$ the union activity involved a strike, an attempt to cause a sympathy strike, boycotting of the employer's product, a secondary boycott of both a contractor doing work for the employer and the employer's lessee, and picketing of the employer. The Supreme Court held that $\$ 20$ of the Clayton Act prevented a criminal conviction under the Sherman Act. The Court stated: "The Norris-LaGuardia Act reasserted the original purpose of the Clayton Act by infusing into it the immunized trade union activities as redefined by the later Act. In this light $\S 20$ removes all such allowable conduct from the taint of being a 'violation of any law of the United States', including the Sherman Law." 104 The Court concluded that ". . . So long as a union acts in its self-interest and does not combine with non-labor groups, the licit and the illicit under $\S 20$ are not to be distinguished by any judgment

100. "The term 'labor dispute' includes any controversy concerning terms or conditions of employment, or concerning the association or representation of persons in negotiating, fixing, maintaining, changing, or seeking to arrange terms or conditions of employment, regardless of whether or not the disputants stand in the proximate relation of employer and employee." 47 STAT. 73 (1932), 29 U.S.C. \$ 113 (1946).

101. "No court of the United States shall have jurisdiction to issue any restraining order or temporary or permanent injunction in any case involving or growing out of any labor dispute to prohibit any person or persons participating or interested in such dispute (as these terms are herein defined) from doing, whether singly or in concert, any of the following acts: (a) Ceasing or refusing to perform any work or to remain in any relation of employment; . . . (e) Giving publicity to the existence of, or the fact involved in, any labor dispute, whether by advertising, speaking, patrolling, or by any other method not involving fraud or violence; ( $f$ ) Assembling peacebly to act or to organize to act in promotion of their interests in a labor dispute; ( $\mathrm{g}$ ) Advising or notifying any person of an intention to do any of the acts heretofore specified; (h) Agreeing with other persons to do or not to do any of the acts heretofore specified. ..."47 STAT. 70-1 (1932), 29 U.S.C. \$ 104 (1946).

102. Injunction may be granted in a labor dispute only after hearing the testimony of witnesses in open court (with the opportunity for cross-examination) and after a finding of fact to the effect: "(a) That uniawful acts have been threatened and will be committed unless restrained ... (b) That substantial and irreparable injury to complainant's property will follow; (c) That as to each item of relief granted greater injury will be inflicted upon complainant by denial of relief than will be inflicted upon defendants by the granting of relief; (d) That complainant has no adequate remedy at law; and (e) That the public officers charged with the duty to protect complainant's property are unable or unwilling to furnish adequate protection. .." 47 STAT. 71 (1932), 29 U.S.C. \$107 (1946). Moreover, no injunction may issue to any complainant ". . . who has failed to make every reasonable effort to settle such dispute either by negotiation or with the aid of any available governmental machinery of mediation or voluntary arbitration." 47 STAT. 72 (1932), 29 U.S.C. \$ 108 (1946).

103. 312 U.S. 219 (1941).

104. Id. at 236 . 
regarding the wisdom or unwisdom, the rightness or wrongness, the selfishness or unselfishness of the end of which the particular union activities are the means. . . ." $10 \mathrm{~s}$

In United States v. Carrozzo, ${ }^{108}$ a union employed strikes and threats to strike to deter use of a labor-saving device, or in the alternative to compel employment of the same number of men who would have been employed but for the device. A federal district court held that this activity involved a "labor dispute" concerning "terms and conditions of employment" within the Norris-LaGuardia Act and therefore $\$ 20$ of the Clayton Act prevented a criminal conviction under the Sherman Act. The Supreme Court affirmed this decision on the basis of the Hutcheson case. ${ }^{107}$

The Carrozzo result is probably unaffected by the passage of the TaftHartley Act. ${ }^{108}$ It is immaterial that the Act makes certain featherbedding activities unfair labor practices and that the Norris-LaGuardia Act is expressly repealed to the limited extent that the NLRB "may" get an injunction in an unfair labor practice situation. ${ }^{109}$ This injunctive discretion was given to the Board to facilitate its application of the policies of the TaftHartley Act, not to overturn the protective provisions of the NorrisLaGuardia Act and $\S 20$ of the Clayton Act. The Taft-Hartley Act in the unfair labor practice situation makes no pretense of permitting the most potent of all anti-labor weapons-an employer injunction. ${ }^{110}$

On the basis of the Carrozzo case, coerced employment involves a "labor dispute" under the Norris-LaGuardia Act where, under threat of strike, work is offered to be done as consideration for wages attempted to be exacted, although this work is unnecessary to efficient operation by the employer. It is probably immaterial that wages will be accepted even though no work is permitted to be done. On the other hand, there is some question whether a "labor dispute" would be involved where the demand is for "protection payments," i.e., payments where work is refused to be done or where work is done or offered to be done merely as a sham. ${ }^{111}$

105. Id. at 232. Accord: Hunt v. Crumboch, 325 U.S. 821 (1945) (suit for injunction and treble damages under the Sherman Act dismissed despite the fact that the defendant union forced the plaintiff trucker out of business solely as punishment for the alleged murder of a union man); cf. Bakery Sales Drivers Local Union No. 33 v. Wagshal, 161 F.2d 380 (D.C. Cir. 1947).

106. 37 F. Supp. 191 (N.D. I11.), aff'd per curiam sib nom. United States v. International Hod Carriers, 313 U.S. 539 (1941).

107. See also United States v. American Federation of Musicians, 47 F. Supp. 304 (N.D. I11. 1942), aff'd zeithout opition, 318 U.S. 741 (1943) (preliminary injunction under Sherman Act denied where union boycotted broadcasting system to force a station within that system to employ stand-by musicians); United States v. Bay Area Painters and Decorators Joint Comm. Inc., 49 F. Supp. 733 (N.D. Cal. 1943). 108. Teller, The Taft-Hartley Act and Govermment by Injunction, 1 LAB. LAw J. $40,45,46$ (1949).

109. 61 StaT. 146 (1948), 29 U.S.C. $\$ 160$ (j) (Supp. 1952).

110. See Amalgamated Ass'n v. Dixie Motor Coach Corp., 170 F.2d 902 (8th Cir. 1948); California Ass'n v. Building and Const. Tr. Council, 178 F.2d 175 (9th Cir. 1949).

111. Sham for this purpose is probably the same as sham for the purpose of felonious intent, see text after note 67 supra. It has been held that a "labor dispute" 
Clearly in the Compagna and Nick situations ${ }^{112}$ no "labor dispute" is involved but merely an attempt at individual enrichment.

Where union striking or picketing does not involve a "labor dispute" under the Norris-LaGuardia Act, Title Two probably would not prevent a conviction under the Hobbs Act. Norris-LaGuardia would not be repealed, modified or affected since it provides no safeguard for non-"labor disputes." However, where striking or picketing does involve a "labor dispute" under the Norris-LaGuardia Act, Title Two probably would prevent a conviction under the Hobbs Act. It is reasonable to conclude, as did the Hutcheson court, that conduct which is allowable on the equity side of the court should not become the road to prison in a criminal proceeding. ${ }^{113}$ Moreover, Hutcheson says that $\S 20$ of the Clayton Act precludes a conviction for a "violation of any law of the United States" when a "labor dispute" is involved. ${ }^{114}$ A completely literal reading of $\$ 20$ is perhaps unjustified because then even a breach-of-the-peace conviction might be improper in a federal court where a "labor dispute" is involved. However, such a consideration has no effect upon the application of the Hobbs Act. Title Two of the Hobbs Act expressly provides that the Act shall not be construed to "repeal, modify or affect" $\$ 20$ of the Clayton Act.

It seems reasonable to conclude that the Clayton and Norris-LaGuardia Acts will provide an extensive safeguard for labor conduct charged as being extortion under Hobbs. Where the coercive activity is striking or picketing which involves a "labor dispute," these Acts will provide protection although the objective of the coercive activity is to force featherbedding. On the other hand, where the coercive activity is labor violence, they will probably afford no substantive safeguards. Only in a situation where the violence is merely incidental to the coercive conduct would a different conclusion be possible. Even picketing becomes enjoinable under the acts where its fundamental characteristic is violence, e.g., mass picketing. ${ }^{115}$ However, there are procedural safeguards which must be met

is involved where a master plumbers association and a local union of plumbers attempted to exact fees from a builder for the "privilege" of installing plumbing equipment. Peterson v. Master Plumbing Ass'n, 44 F. Supp. 908 (D. Nev. 1942). This case can be distinguished from "protection payments" on the ground that the attempted exaction was incident to an offer to work.

112. See text at note 12 supra.

113. United States v. Hutcheson, 312 U.S. 219, 234 (1941).

114. There are indications that $\$ 20$ of the Clayton Act prevents the application of the Sherman Act to striking or picketing which does not involve a "labor dispute." See Hunt v. Crumboch, 325 U..S. 821 (1945) (union punishing employer for alleged murder of union man). If this interpretation of $\$ 20$ is adopted for the purposes of Title Two, $\$ 20$ would preclude a Hobbs conviction even in the Compagna and Nick situations. It seems desirable therefore to limit the Hunt case contruction of $\$ 20$ to the application of the Sherman Act. This limitation is reasonable in light of the fact that Hunt's interpretation of $\$ 20$ was motivated by a feeling that the Sherman Act is particularly inapplicable when labor conduct is in question. $C f$. United States v. United Mine Workers, 330 U.S. 258, 270 (1947), where it was said that for injunction purposes, the protections of Norris-LaGuardia are more inclusive than those of Clayton.

115. General Electric Co. v. Gojack, 68 F. Supp. 686 (N.D. Ind. 1946); Lake Charles Stevedores, Inc. v. Mayo, 20 F. Supp. 698 (W.D. La. 1935); Cater Const. Co. v. Nischwitz, 111 F.2d 971 (7th Cir. 1940). 
under the Norris-LaGuardia Act before an injunction can issue against violence in a labor dispute. ${ }^{116}$ Although injunctive power is thus limited, it is not necessarily a sequitur that a Hobbs conviction is thereby precluded by Title Two. The Supreme Court has said that criminal proceedings can be entirely in order despite the fact that an injunction is improper under the Norris-LaGuardia Act because of a failure to comply with one of its safeguards. ${ }^{117}$

Railway Labor Act.-Only brief mention need be made of the significance of the inclusion of the Railway Labor Act in Title Two. The fact that this Act protects the right to strike ${ }^{118}$ would seem to be of little. consequence in light of the fact that the Clayton and Norris-LaGuardia Acts apply equally well to labor disputes in the railroad industry. ${ }^{119}$ There are no indications of labor protections afforded by the Railway Labor Act which are not provided by Clayton and Norris-LaGuardia.

There are two instances, however, when a peaceful strike is enjoinable despite the Railway Labor, Clayton, and Norris-LaGuardia Acts. An injunction is permissible when a union strikes without first meeting the conditions precedent under the Railway Act to the right to strike. ${ }^{120}$ But this failure to meet the conditions precedent may not necessarily mean that the protections of Title Two are lost. An injunction in this instance is merely a temporary restraint to insure the use of the procedures of the Railway Labor Act designed to facilitate the settlement of labor disputes. If these procedures prove ineffective, striking is not then enjoinable.

The other instance where a strike is enjoinable despite the Railway, Clayton, and Norris-LaGuardia Acts is where the strike is against the Federal Government which has seized the railways because of a national emergency affecting the war effort. ${ }^{121}$ Likewise, in similar seizures in industries other than the railways, the labor statutes do not preclude the enjoining of a strike against the United States, since the government is not an "employer" under Norris-LaGuardia. ${ }^{122}$ Moreover, there is dictum to the effect that even in the absence of government seizure, a strike is enjoinable when it threatens to disrupt the structure of the national society. ${ }^{123}$ In these instances Title Two may afford no protection.

116. See note 102 supra.

63 (1944).

117. Brotherhood of Railroad Trainmen v. Toledo, P. \& W. R.R., 321 U.S. 50,

118. 48 StAT. 1186 (1934), 45 U.S.C. $\$ 152$ (1946).

119. Brotherhood of Railroad Trainmen v. Toledo, P. \& W. R.R., 321 U.S. 50 (1944) (labor violence enjoinable only after Norris-LaGuardia procedural safeguards had been complied with).

120. Anderson v. Bigelow, 130 F.2d 460, 461 (9th Cir. 1942) reversing on other grounds, In re Virginia \& Truckee Ry., 36 F. Supp. 119 (D. Nev. 1941) in which a decision on failure to meet conditions was implicit in the issuance of an injunction.

121. United States v. Brotherhood of Locomotive Engineers, 79 F. Supp. 485 (D.D.C. 1948).

122. United States v. United Mine Workers, 330 U.S. 258 (1947).

123. United States v. Brotherhood of Locomotive Engineers, 79 F. Supp. 485, 487 (D.D.C. 1948). 
The net effect of Title Two.-A final observation need be made about the interrelation of Title Two and the substantive crime of extortion. Under the proposed interpretation, Title Two would afford protection in the coerced employment situation where the coercive activity consists of peaceful striking or picketing which involves a "labor dispute" under the NorrisLaGuardia Act. A "labor dispute" requires proof merely of a bona fide offer to work.124 Therefore, it is immaterial in the case of peaceful striking or picketing whether or not the felonious intent required by the substantive crime of extortion ${ }^{125}$ precludes a conviction where a bona fide offer to work is made. The limitations imposed by the requisite felonious intent are vital, however, where the labor activity is fundamentally violent and hence unprotected by Title Two.

A conclusion that the requirement of felonious intent precludes a conviction where a bona fide offer to work is made, probably renders Title Two surplusage. ${ }^{128}$ This conclusion is not unreasonable in light of the legislative history which surrounded the passage of the Hobbs Act. State statutes of the New York type do not have protective provisions like Title Two. It may have been inserted in the Act in an overly cautious gesture toward union rights. It is difficult to conclude that the President vetoed the original Hobbs Bill because it lacked a Title Two; the Hobbs Bill just happened to be part of the larger Case Bill which the President rejected. In his veto message, the President merely said that "some question may arise" from the fact that section 6 of the original Act was omitted. ${ }^{127}$ It is quite understandable that Congress would take the course of least resistance and return the bill with a "Title Two" included, thereby cleaning its hands of charges of anti-labor legislation.

\section{SUMMMARY}

The Hobbs Act is the confused product of legislative reaction to violent disruption of interstate commerce by labor. It is indeed doubtful whether Congress fully appreciated the various ramifications of the application of the crime of extortion to wage demands, particularly the possible limitations imposed by a requirement of felonious intent. It is unfortunate that the Supreme Court, by refusing to grant certiorari in the Kemble case, has denied itself the opportunity of comprehensive judicial clarification. In the absence of such a guide, only an attempt can be made to resolve the conflicts raised.

124. See text after note 110 supra.

125. See text at note 67 supra for conclusions as to felonious intent.

126. This view is not inconsistent with legislative history. The Report of the House Committee on the Judiciary stated that "[I]t is not the intention of the committee that ... [Title Two] . . . be interpreted as authorizing any unlawful acts, particularly those amounting to robbery and extortion. The need for the legislation was emphasized by the opinion of the Supreme Court in the case of United States v. Local 807. . . ." H.R. No. 238, 79th Cong., 2d Sess.; U.S.C. Cong. Ser. 1360, 1370 (1946).

127. See text at note 85 supra. 